\title{
Interpretation needs and preferences of visitors to Kgalagadi Transfrontier Park
}

\begin{tabular}{|c|c|}
\hline $\begin{array}{l}\text { Authors: } \\
\text { Petrus van der } \\
\text { Melville Saayn } \\
\text { Elricke Botha }{ }^{2}\end{array}$ & $\begin{array}{l}\text { Merwe }^{1} \text { (I) } \\
\operatorname{lan}^{1} \text { (D) } \\
\text { (D) }\end{array}$ \\
\hline $\begin{array}{l}\text { Affiliations: } \\
{ }^{1} \text { School of Tou } \\
\text { Management, } \\
\text { Research in Ec } \\
\text { Environs and S } \\
\text { of Economic a } \\
\text { Management } \\
\text { North-West U } \\
\text { Potchefstroom }\end{array}$ & $\begin{array}{l}\text { rism } \\
\text { Tourism } \\
\text { onomics, } \\
\text { ociety, Faculty } \\
\text { nd } \\
\text { Sciences, } \\
\text { hiversity, } \\
\text {, South Africa }\end{array}$ \\
\hline $\begin{array}{l}{ }^{2} \text { Department } \\
\text { Management, } \\
\text { Economic and } \\
\text { Sciences, Univ } \\
\text { Africa, Pretori }\end{array}$ & $\begin{array}{l}\text { f Applied } \\
\text { College of } \\
\text { Management } \\
\text { ersity of South } \\
\text {, South Africa }\end{array}$ \\
\hline $\begin{array}{l}\text { Correspondin } \\
\text { Elricke Botha, } \\
\text { vlogge@unisa }\end{array}$ & $\begin{array}{l}\text { author: } \\
\text { ac.za }\end{array}$ \\
\hline $\begin{array}{l}\text { Dates: } \\
\text { Received: } 05 \\
\text { Accepted: } 17 \text { J } \\
\text { Published: } 11\end{array}$ & $\begin{array}{l}\text { ec. } 2019 \\
\text { une } 2020 \\
\text { Aug. } 2020\end{array}$ \\
\hline $\begin{array}{l}\text { How to cite th } \\
\text { Van der Merw } \\
\text { Saayman, M. } \\
\text { 2020, 'Interpr } \\
\text { and preferenc } \\
\text { to Kgalagadi Tr } \\
\text { Park', Koedoe } \\
\text { https://doi.org } \\
\text { koedoe.v62i1. }\end{array}$ & $\begin{array}{l}\text { is article: } \\
\text {, P., } \\
\text { Botha, E., } \\
\text { tation needs } \\
\text { s of visitors } \\
\text { ansfrontier } \\
2(1) \text {, a1613. } \\
/ 10.4102 / \\
1613\end{array}$ \\
\hline $\begin{array}{l}\text { Copyright: } \\
\text { (C) 2020. The A } \\
\text { Licensee: AOS } \\
\text { is licensed unc } \\
\text { Creative Comn } \\
\text { Attribution Lic }\end{array}$ & $\begin{array}{l}\text { uthors. } \\
\text { S. This work } \\
\text { er the } \\
\text { eons } \\
\text { ense. }\end{array}$ \\
\hline Read online: & \\
\hline 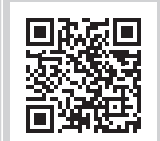 & $\begin{array}{l}\text { Scan this QR } \\
\text { code with your } \\
\text { smart phone or } \\
\text { mobile device } \\
\text { to read online. }\end{array}$ \\
\hline
\end{tabular}

South African National Parks is one of South Africa's main drawcards for ecotourists. One of these parks is the Kgalagadi Transfrontier Park (KTP), which is also a World Heritage Site (WHS). Because tourism is key to national parks and WHSs, visitor management strategies such as interpretation are vital for these destinations to provide tourists with better experiences and knowledge. The aim of this research was therefore to determine the interpretation needs and preferences of visitors to KTP. The factor analyses revealed that tourists felt that park guidelines would add the most to a quality experience. Tourists preferred interpretation topics on nature and heritage and would like to receive in-depth information on these topics. Interpretation should also preferably be offered through audio and visual media. These findings impact the development of relevant interpretation services for the park, which will contribute towards visitors' experiences. The research is original as it examined visitors' interpretation needs and preferences on topics, the extent of information tourists would like to receive and the type of media through which information should be presented.

Conservation implications: Designing relevant interpretation services based on tourists' needs and preferences will contribute towards satisfactory experiences. In turn, this may lead to an increase in profits, which can support conservation practices. Effective interpretation messages can also foster additional support towards conservation efforts.

Keywords: ecotourism; wildlife tourism; national parks; education; interpretation; World Heritage Site.

\section{Introduction}

The main objective of most national parks in the world, and in South Africa specifically, is to conserve the environment or biodiversity (South African Government 1976), but this has proven to be quite a difficult task to perform because of declining public funding (Eagles 2014). South African National Parks (SANParks; the managing body of South African national parks) is therefore primarily a self-funding entity, as ecotourism activities generate $80 \%$ of the total income of national parks (SANParks 2018). Ecotourism thus contributes to sustaining the conservation objectives of the national parks (SANParks 2018).

Considering that there has been a decline in public funding and that ecotourism activities generate such a large percentage of SANParks' income $(80 \%)$, its focus concerning visitor management is to manage visitor experience through soft visitor management (e.g. influencing enjoyment, attitudes and values through displays, signage or the website, to name but a few) and hard visitor management (e.g. regulating human impact through physical facilities such as bird hides or boardwalks, to name but a few) (SANParks 2018). The manager of Visitor Management and Interpretation of SANParks' Tourism Division stated that interpretation has been identified by SANParks as a means of not only adding to the funding required for conservation, but in itself also contributing towards conservation and the tourism experience (Moore 2017; personal interview 17 January 2017). The visitor manager further indicated that the requirement is to deliver well-planned and carefully designed interpretation services to help visitors understand what happens in national parks and also educate them on conservation, culture and ecotourism.

The park selected as a case study for this research was Kgalagadi Transfrontier Park (hereafter KTP), as it had been identified by SANParks' management as a priority park for developing interpretation services (Moore 2017). Kgalagadi Transfrontier Park has a unique cultural heritage and rich history, but also varied biomes and plentiful fauna and flora (South Africa 2019), which draw visitors to the park. Visitors want information about these aspects, but the park has limited facilities and services to satisfy their needs. At present only three tourist camps, Twee Rivieren, Nossob and Mata Mata, have information and/or interpretation centres; 
however, they are very basic with nothing but a few displays and posters (Moore 2017). Moreover, the park was added to the United Nations Educational, Scientific and Cultural Organisation (UNESCO) World Heritage Site (WHS) list in 2017 (UNESCO 2019a), which inevitably will increase tourist interest in the park. In addition, the Protected Areas Act (57 of 2003) indicates that protected areas (South Africa 2003) such as KTP are mandated to offer visitor facilities and that such facilities should be established in response to market demands.

It is against this backdrop that the park has considered refining their interpretation services based on visitors' needs and preferences, hence this research. Determining visitors' needs and preferences for interpretation services will assist SANParks to develop relevant interpretation services for the park that will contribute towards the visitor experience.

\section{Literature background \\ Educational experiences within ecotourism}

It is well known that education and learning form part of an ecotourism product. This is evident in both the range of definitions of ecotourism as well as research conducted on the topic. Ceballos-Lascurain (1987), the first author to do so, defined ecotourism as travelling to relatively undisturbed or uncontaminated natural areas for studying, admiring and enjoying the scenery, its wild plants and animals, or any past and existing cultural manifestations found in the area. Fennell (2003), on the other hand, defines ecotourism as a sustainable form of natural resource-based tourism that focuses primarily on experiencing and learning about nature and should contribute to the conservation of such areas. Geldenhuys (2009) concurs with Fennell's (2003) definition and explains that ecotourism occurs in natural settings that are ecologically sustainable and enables tourists to interpret and learn about the environment they are visiting (i.e. environmental education).

The notion of learning in ecotourism is also evident in the range of research studies conducted on ecotourists. Even though ecotourists are not homogenous, research has shown that most ecotourists prefer information-rich experiences. Sheena, Mariapan and Aziz (2015) found that 'hard' ecotourists rated 'tendency to learn' significantly higher than other ecotourists, whilst 'structured' ecotourists (falling between 'hard' and 'soft' ecotourists) also indicated a strong preference for the learning component. The quality of a tour guide (verbal transfer of information), the quality of information and digital forms of information were found to be key factors in selecting ecotourism products in the study conducted by Cheung and Jim (2013). These authors also researched the difference between nature tourists and general tourists in a follow-up study and found that nature tourists had higher expectations of the guide, the information provided and the ecological importance of the destination than general tourists did (Cheung \& Jim 2014). Chen and Jim (2012) researched the potential value of ecotourism development (i.e. country parks) in Hong Kong and found that the motivation 'to experience and learn more about nature' ranked as the most important factor for ecotourism development, followed by 'rest and relax in a pleasant setting'. In South Africa, ecotourists to the Kruger National Park expect interpretation services in the park because all three factors identified (i.e. primary, secondary and knowledgeable staff) were revealed to be very important to the quality of visitors' experience (Botha, Saayman \& Kruger 2016). Primary interpretation refers to immediately recognised interpretation (e.g. visitor centre), whereas secondary interpretation refers to interpretation that is auxiliary to the broader activity (e.g. commentary on a game drive) or indistinct (e.g. Web-based marketing of the game drive). These factors were labelled according to Stewart et al.'s (1998) classification (discussed later in the study).

\section{Interpretation}

Carmody and Prideaux (2011) state that interpretation is similar to communication. The reason is that interpretation incorporates all the various ways in which attraction or destination managers (in this case, KTP) seek to communicate with their visitors (Moscardo \& Ballantyne 2008) (see Figure 1). Interpretation, therefore, also includes a context (i.e. the national park's wildlife and heritage); a sender (e.g. the national park's managers through interpretation centres); a message (e.g. information regarding conservation and heritage), which can be verbal or non-verbal; a medium (e.g. a podcast, brochure, game drive or exhibit); a receiver (e.g. the ecotourist); and feedback (e.g. visitor enjoyment) (Schiffman \& Kanuk 2007).

What makes interpretation different from other forms of information transfer is that interpretation aims to translate the technical language and content of natural science and related fields into simple ideas and illustrations that any person can understand (Ham 1992). Against this background, various authors have researched this concept and concluded that successful interpretation should be enjoyable, personally relevant and organised, make use of themes and a variety of presentations or mediums, provide time for reflection (allowing visitors to think deeply and draw their own conclusions), involve all the senses, communicate the significance of the place visited and allow personal control (Ballantyne, Packer \& Falk 2011; Ham 1992; Ham, Housego \& Weiler 2005; Tilden 1977).

Tilden (1977), considered to be the father of interpretation, explains interpretation as an educational activity that aims to reveal meanings and relationships through first-hand

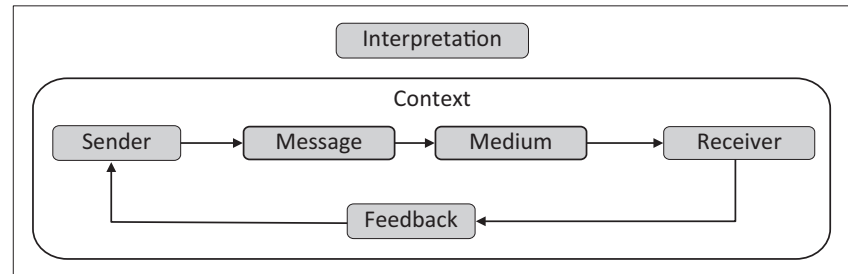

FIGURE 1: Components of interpretation. 
experiences, the use of original objects and illustrative media, rather than simply to communicate factual information. From a national park's perspective, interpretation is a means to manage visitors' educational expectations, because visitors to national parks are well educated and expect information-rich experiences (Botha et al. 2016; Jurdana 2009). Interpretation services, therefore, add value to the tourist's experience (Ballantyne, Packer \& Sutherland 2011; Ham \& Weiler 2006) and lead to a range of other benefits such as increased satisfaction, loyalty, purchasing and revenue, as well as visitors spending more time in the national park, encouraging other visitors to visit the park and providing positive word-of-mouth referrals for the park (De Rojas \& Camarero 2008; Lee 2009; Zeppel \& Muloin 2008).

Added to the various benefits associated with interpretation is also the potential to improve conservation initiatives. The information communicated to tourists broadens their knowledge about the place they are visiting by focusing the message on the significance of their experiences and deepens their understanding of conservation (Reisinger \& Steiner 2006). This understanding creates respect and concern for species (Ballantyne et al. 2011) and leads to support for nature conservation work (Zeppel \& Muloin 2008). As stated by Baba Dioum, 'In the end, we will conserve only what we love, we will love only what we understand and we will understand only what we are taught' (Dioum 1968).

Interpretation can be delivered in a variety of ways. Tilden (1977) explains that interpretation can either be attended or unattended. Attended interpretation refers to services delivered in person, such as discussions or talks, whereas unattended interpretation (i.e. without personal contact) refers to services delivered through signs, labels, self-guided trails (for hikes or vehicles), exhibits, publications and visitor centres. Ward and Wilkinson (2006) concur with this classification and refer to interpretation as personal or nonpersonal. Other authors have more elaborate classifications. Kuo (2002) based his on Orams' (1996) ecotourism management strategies: hard interpretation includes physical (e.g. pathways or bird hides), regulatory (e.g. rules and regulations) and economic (e.g. fines and fees) management strategies, whereas soft interpretation refers to educational (e.g. behavioural information and education) management strategies (Kuo 2002; Orams 1996). Further to this, Stewart et al. (1998) refer to primary, secondary and tertiary interpretation. Primary interpretation overlaps with Kuo's (2002) soft interpretation or Orams' (1996) educational management strategy, where the interpretation is conspicuous, noticeable and immediately recognised as interpretation. Secondary interpretation is auxiliary to a wider activity and forms an integral feature of the activity. Tertiary interpretation is hidden, obscure and indistinct as an interpretive activity and is not always considered to be interpretation. Both secondary and tertiary interpretation can therefore be considered to overlap with Kuo's (2002) hard interpretation and Orams' (1996) physical, regulatory and economic management strategies.
As visitor services, such as interpretation, should be established in response to market demands (Haely, Van Riper \& Boyd 2016; South Africa 2003), it is imperative to have a closer look at the market's (i.e. the receiver's) demands in terms of the components of interpretation to effectively design such services and facilities (i.e. product development). The next sections will therefore present a closer look at the context, message and medium of interpretation for which tourists may have specific needs and preferences.

\section{The context of interpretation}

Keyton and Beck (2010) explain that the context in communication, and therefore interpretation, is multidimensional because it is composed of all internal and external influences that affect the communication process. Destinations typically cannot control, or may find it difficult to control, the internal influences (i.e. within the visitor) that can affect the communication process, but they are in a position to control the external influences.

Bidder, Kibat and Fatt (2016) found that some of the top motivations to visit the Kinabalu Park were destination specific, such as 'to climb Mount Kinabalu', 'because the Park was one of the must-see attractions in Sabah' and 'to experience the indigenous cultural value of Mount Kinabalu'. Cheung and Jim (2014) found that 'ecological value' and 'good destination management' were the two most important factors in destination choice in Hong Kong's conservation areas. The factor 'ecological importance of destination' was also positively correlated with willingness to pay (Cheung \& Jim 2013). Sheena et al. (2015) concluded that high-interaction programmes involving nature in Kinabalu Park should be offered because the park enhances a profound spiritual connection. From an interpretation perspective, ecotourism managers should identify the unique destination characteristics related to physical, social, historical, psychological and cultural factors to guide the interpretation topics that could be of interest to tourists. Ballantyne, Hughes and Bond (2016) determined the preferred topics among Canterbury Cathedral WHS owners or managers and reduced the 68 topics to 21. Different from this study, however, is that their research was not within a natural destination context such as KTP and was based on the preferences of owners or managers and not tourists. As Moscardo (2014) explains, those responsible for interpretation are also the ones in power, and they decide which aspects will be presented to tourists. It is therefore crucial to determine tourists' preferences in terms of interpretation topics. One such study that did research from a tourist perspective, but within a marine context in New Zealand, was that by Lück (2015). Although tourists were generally satisfied with the whale and dolphin tours, they also wanted to learn more about wildlife and the sea in general (Lück 2015), thereby amplifying the fact that tourists might have different preferences than managers or owners.

As mentioned by the visitor manager of SANParks, in the case of KTP the context that needs interpretation is the culture 
of the area (łKhomani and the related San people) and the rich fauna and flora of the semi-desert habitat (Moore 2017). (More detail on the unique context of this park can be found under the 'Research methods and design' section.) Although this is the case, it would be worthwhile to determine the preferences of tourists in this regard.

\section{The message of interpretation}

As previously explained, ecotourists have a high tendency to learn (Sheena et al. 2015) and consequently have higher expectations of interpretation (Cheung \& Jim 2014). Careful consideration should therefore be given to the extent of information on the topics selected (see the 'context of interpretation' discussed previously) and how the topics are presented in interpretation.

Whilst topics and themes are often used interchangeably, Ham (1992) explains that topics are the subject matter, whilst themes refer to the message about the topic. For example, one of the topics in an interpretation centre might be 'water'. The theme, on the other hand, places specific emphasis on the message to 'conserve water' by providing relevant information to the tourists that is enjoyable. The method in which this message is delivered not only highlights the importance of water but also illustrates how the tourist can contribute to the conservation thereof. It is against this background that the theme refers to the messages of interpretation.

According to Ham (1992), themes should have the qualities of a story: a beginning and end, moral and little meanings (analogies and concepts) that add to the big meaning. Langer (1989), a theorist on mindfulness-mindlessness, explains that environments characterised by novelty, surprise, complexity and ambiguity could induce mindful states (i.e. readiness for cognitive processing). Interpretation should also be relevant (Ham 1992) by including practical examples of how visitors could contribute towards conservation (Ballantyne et al. 2011; Marschall, Granquist \& Burns 2017); interpretation should provide personal connection (Tilden 1977) and allow visitors to reflect on personal meaning (Kolb 1984). Interpretation messages that focus on emotions have a greater effect on conservation intentions (Jacobs \& Harms 2014). Ballantyne et al. (2011) explain that interpretation should let visitors use their imagination, provide information about the dangers faced by animals as a result of human actions, provide examples of how visitors' everyday behaviours can have either a positive or negative impact on the animals being observed and supply practical yet achievable examples of what visitors can do to contribute to animal and environmental welfare. Ecotourism destinations should therefore not only select their topics carefully, but also consider the theme or message to portray the topic wisely. Further advice from Ballantyne, Packer and Hughes (2009) is that ecotourism destinations should make sure that these themes or messages are delivered in a consistent manner, because inconsistencies can undermine the credibility of the interpretive message. To the researchers' knowledge, little research has been conducted to determine tourists' preferences in terms of the extent of information on topics for interpretation services. However, Marschall et al. (2017) found that teleological signs (i.e. information with explanations) were more effective than ontological signs (i.e. information without explanations) in modifying visitors' behaviour. This may indicate that visitors rather prefer more information than less information on topics (i.e. the extent of their interest). However, some topics might be of more interest than others and may have different preferences in terms of the extent of information visitors prefer.

\section{The medium of interpretation}

The medium of communication is defined as the physical space, means of sending information or the route the message travels (Schindler, Ruoppolo \& Barillari 2010). The medium in interpretation can therefore be seen as the vehicle through which the themes and messages are delivered to tourists (Ham et al. 2005).

Ballantyne et al. (2011) suggest that interpretation design should incorporate multiple senses (sound, smell, textures and visually appealing aspects) and use interpretive commentaries and signage to reinforce a sense of wonder, awe, excitement and privilege (i.e. non-verbal communication); time and space should be created for visitors to reflect on the experience and meaning (i.e. organised interpretation); staff or volunteer guides should be available to answer visitors' questions (i.e. verbal communication); resources should be provided to visitors to access after the visit to follow up on specific interests (i.e. off-site interpretation). Bidder et al. (2016), on the other hand, explain that information should be presented in various forms (print, display and audiovisual shows), and souvenirs should be sold as part of the interpretation experience (i.e. post-experience). Interestingly, Haely et al. (2016) found that low-intensity technologically driven interpretation displays were preferred over highintensity displays at the Cliffs of Moher in Ireland's (i.e. natural area) visitor centre. Marschall et al. (2017) explain that illustrations in interpretation signs are necessary, not only to attract visitors but also to enable children to understand the interpretation. The positioning of signs is important to attract visitors, and the height at which these signs are positioned should be suitable for children to admire (Marschall et al. 2017).

Other authors studied the effectiveness of certain mediums. Cheung and Jim (2013) found that respondents participating in a study in natural environments in Hong Kong preferred digital over printed interpretation. Henker and Brown (2011) found that online interpretive programmes (i.e. podcasts) were virtually as effective a means as traditional ranger programmes to foster visitor connections. Kang and Gretzel (2012) concurred with the findings of Henker and Brown (2011) and advised that podcast tours developed by multiple narrators using a conversational narration style would probably increase the effectiveness of the visitor's experience. Mitsche et al. (2008) explored e-services (e.g. interactive maps, 3-D applications, virtual tours, online exhibitions, interactive resources, games, online collections and online shops) for 
interpretation purposes and found them to be effective; they also identified a need to cater for different target groups.

As this study aims to determine the interpretation needs and preferences of visitors to KTP, the objective is to provide answers to the following questions to develop relevant interpretation services: What are the interpretation services needed by tourists visiting the national park? What are the topics or types of information visitors are interested in? Do visitors prefer specific mediums through which the topics or information should be presented?

Answering these questions will assist the park in developing successful interpretation services and facilities according to the needs and preferences of tourists and will provide researchers with greater insight into visitors' needs and preferences concerning interpretation.

\section{Research methods and design Study site}

The KTP is one of the 19 national parks managed by SANParks, and it is unique in that it is a transfrontier park extending into Namibia and Botswana. Transfrontier parks or transfrontier conservation areas (TFCA) are defined as 'relatively large areas, straddling frontiers between two or more countries and covering large-scale natural systems encompassing one or more protected areas' (South Africa 2004). Kgalagadi Transfrontier Park was the first chapter in TFCAs in Southern Africa and was opened on 12 May 2000 (South Africa 2004). As indicated previously, the park was also included on the UNESCO WHS list in 2017, based on the evidence of human occupation from the Stone Age. It is associated with the Khomani San people, which is a unique African cultural group (UNESCO 2019a). Among the 19 national parks, KTP and Mapungubwe National Park are the only two national parks inscribed as WHSs (SANParks 2018). These two national parks feature among other well-known South African UNESCO cultural sites, such as fossil hominid sites, Richtersveld Cultural and Botanical Landscape and Robben Island (UNESCO 2019b).

\section{Study design}

A quantitative study was conducted by means of a structured questionnaire to determine tourists' interpretation needs and preferences in KTP.

\section{Study population and sampling strategy}

A non-probability sampling method, convenience sampling, was used to conduct the survey. Convenience sampling means that the researchers include participants who were the most conveniently available (Quinlan et al. 2019). Krejcie and Morgan (1970) state that when the population is over 1000000 , the minimum sample size should be 384 . The level of precision is $5 \%$ to compensate for questionnaires with sampling errors (e.g. questionnaires that are not returned or are incomplete).
The research population for this research consisted of overnight visitors to KTP for the period February 2016 to January 2017. The number $(N)$ of visitors was 1983, and the questionnaire was sent to their email addresses by SANParks with a letter explaining the importance and aim of the research. The completed questionnaires received back from respondents totalled 562 .

\section{Questionnaire development}

The questionnaire consisted of six sections comprising openand closed-ended questions as well as Likert and semantic differential scale-type questions. This research formed part of a bigger project, and only selected sections of the questionnaire were used for this article.

Section A consisted of questions relating to the respondents' demographic and biographical profiles. Section D determined tourists' agreement with the inclusion of interpretation topics and/or information in a visitor centre $(1=$ strongly disagree to $5=$ strongly agree) and prompted the respondents to indicate to what extent they would like information on the topics and/or information listed in the questions $(1=$ to a very little extent to $5=$ to a very great extent). The variables (i.e. topics) in this section were based on parkspecific characteristics such as the fauna and flora of the park (SANParks 2020a), the transfrontier aspects (South Africa 2019), and the World Heritage listing (UNESCO 2019a). Section E contained questions about the importance of interpretation services for a quality experience in the park as a whole, as well as the importance of specific media in an interpretation visitor centre. Both questions had to be answered according to a scale of 1 (not at all important) to 5 (extremely important) and were based on the works of Ballantyne et al. (2011), Botha et al. (2016), Bidder et al. (2016), Cheung and Jim (2013), Henker and Brown (2011), Jacobs and Harms (2014), Kang and Gretzel (2012), Kolb (1984), Kuo (2002), Langer (1989), Marschall et al. (2017), Mitsche et al. (2008), Orams (1994), Stewart et al. (1998) and Tilden (1977).

\section{Data analysis}

The data obtained from the survey were captured in Microsoft Excel and subsequently statistically analysed using Statistical Package for Social Sciences version 16 (Field 2013). The data analysis consisted of three phases. In the first phase, data analysis of the descriptive results (e.g. age, gender, home language and place of residence) revealed the profile (demographics) of the respondents. In the second phase, a principal component analysis with an oblimin rotation and Kaiser normalisation was performed on the 14 interpretation service preference items, 18 preferred topics and/or information items, 18 items on the extent of information on the topics and/or information, and 18 preferred medium items in order to improve the interpretability of each factor structure. A Kaiser-MeyerOlkin (KMO) value $>0.7$ is deemed acceptable (Kaiser 1974). As a result, all factors with eigenvalues larger than one 
were used, and all items with a factor loading $>0.3$ were considered as contributing towards a factor (Field 2013). Items with a factor loading $>0.4$ that cross-loaded onto two factors were categorised in the factor where interpretability was best. All factors with a Cronbach's alpha above 0.6 and inter-item correlations between 0.15 and 0.55 (Cohen 1988) were considered acceptable as reliability indicators. Factor scores were calculated as the average of all items contributing to that particular factor to interpret them on the applicable five-point Likert scale.

\section{Ethical considerations}

The research went through a rigorous ethics application process (the University of South Africa, clearance number 2016_CEMS_ESTTL_007). Although the research involved human participants, the research was deemed 'low risk'. The questions in the questionnaire did not include any personal identifiers or sensitive information, and even if the informed consent was obtained before a respondent completed a questionnaire, the respondent was entitled to withdraw from the study at any point in time.

\section{Results}

This section consists of two parts: first, the profile of the respondents, and second, the factor analysis-based preferences for interpretation services, topics and/or information, the extent of information and interpretation mediums.

\section{Profile of respondents}

The profile of respondents to the KTP questionnaire can be summarised as male, with an average age of 59, mainly Afrikaans or English speaking, from the Western Cape and Gauteng provinces, with a diploma or degree, staying on average 6.4 nights and having visited the park on average seven times. The sociodemographics of the research subjects (profile), namely average age, language spoken, place of residence and level of education, correspond with the results of previous researchinto the profile(sociodemographics) of visitors to Mapungubwe National Park conducted by Hermann et al. (2015), to Kruger National Park conducted by Saayman and Van der Merwe (2017), Van der Merwe, Saayman and Pienaar (2009) and Van der Merwe and Saayman (2008) and to all South African national parks conducted by De Witt, Van Der Merwe and Saayman (2015) and Du Plessis, Van der Merwe and Saayman (2013). The fact that the profile resulting from this study coincides with previous research adds to the validity of the profile of visitors to natural areas in South Africa (Table 1).

\section{Interpretation services}

The aim of the questions in Figure 2 was to determine the interpretation services wanted by tourists to KTP. Respondents indicated that they needed park guidelines (Factor 1), activity involvement (Factor 2) and information structures (Factor 3) for a quality experience in the park.
All three factors had a Cronbach's alpha loading of above 0.7 with an inter-item correlation above 0.4 . A factor loading of 0.30 is considered significant, whilst a factor loading of 0.50 is considered highly significant (Field 2013).

The highest rated factor was Factor 1, park guidelines, with a mean value of 4.30 . This factor consisted of constructs such as park rules and regulations clearly communicated through

TABLE 1: Park respondents' profile.

\begin{tabular}{ll}
\hline Sociodemographic characteristics & Results \\
\hline Gender & Male $(67 \%)$ \\
Age & Average of 59 years \\
Home language & Afrikaans $(47 \%)$, English $(45 \%)$ \\
Province of residence & Western Cape $(38 \%)$, Gauteng $(27 \%)$ \\
Annual gross income & $>$ R672 001.00 (40\%) \\
Level of education & Diploma, degree $(37 \%)$ \\
Number of people in travelling group & Average of 3.4 people \\
Length of stay & Average of 6.4 nights \\
\hline
\end{tabular}

\begin{tabular}{|c|c|c|c|}
\hline \multicolumn{4}{|c|}{ Pattern matrix } \\
\hline \multirow[t]{2}{*}{ Variance $56.4 \%$} & \multicolumn{3}{|c|}{ Component } \\
\hline & Factor 1 & Factor 2 & Factor 3 \\
\hline \multicolumn{4}{|l|}{ Park guidelines } \\
\hline $\begin{array}{l}\text { Park rules and regulations clearly } \\
\text { communicated through signs and } \\
\text { brochures }\end{array}$ & 0.826 & - & - \\
\hline $\begin{array}{l}\text { Clear directions in the park (e.g. to } \\
\text { picnic areas and rest camps; } \\
\text { travelling time) }\end{array}$ & 0.759 & - & - \\
\hline $\begin{array}{l}\text { Knowledgeable staff who can handle } \\
\text { any queries (general information as } \\
\text { well as specialised information } \\
\text { about the park) }\end{array}$ & 0.724 & - & - \\
\hline $\begin{array}{l}\text { Relevant information and activities } \\
\text { of the park should be shown on the } \\
\text { website }\end{array}$ & 0.581 & - & - \\
\hline $\begin{array}{l}\text { Map of the park provided at no } \\
\text { additional cost (because of safety/ } \\
\text { security/information reasons) }\end{array}$ & 0.486 & - & - \\
\hline \multicolumn{4}{|l|}{ Activity involvement } \\
\hline $\begin{array}{l}\text { Cuisine experiences (e.g. game } \\
\text { dishes or local cultural dishes) }\end{array}$ & - & 0.834 & - \\
\hline $\begin{array}{l}\text { Event nights (e.g. stargazing } \\
\text { sessions, educational movies on } \\
\text { nature or cultures, photography } \\
\text { sessions) }\end{array}$ & - & 0.774 & - \\
\hline $\begin{array}{l}\text { Experience the local culture or } \\
\text { community's way of life }\end{array}$ & - & 0.766 & - \\
\hline $\begin{array}{l}\text { Additional books, magazines or } \\
\text { newspapers for sale with } \\
\text { information on the environment, } \\
\text { conservation or astrology }\end{array}$ & - & 0.608 & - \\
\hline $\begin{array}{l}\text { Game drives with interactive field } \\
\text { guides }\end{array}$ & - & 0.478 & - \\
\hline \multicolumn{4}{|l|}{ Information structures } \\
\hline $\begin{array}{l}\text { Bird hides in the park shown in static } \\
\text { displays }\end{array}$ & - & - & 0.877 \\
\hline $\begin{array}{l}\text { Lookout points in the park shown in } \\
\text { static displays }\end{array}$ & - & - & 0.743 \\
\hline $\begin{array}{l}\text { Identification of trees (e.g. } \\
\text { nameplates or information boards) }\end{array}$ & - & - & 0.729 \\
\hline $\begin{array}{l}\text { Information board with sightings of } \\
\text { the day }\end{array}$ & - & - & 0.629 \\
\hline Cronbach's alpha & 0.79 & 0.774 & 0.774 \\
\hline Mean value & 4.3 & 3.36 & 4.15 \\
\hline Inter-item correlation & 0.431 & 0.41 & 0.474 \\
\hline \multicolumn{4}{|c|}{ Extraction method: principal component analysis } \\
\hline \multicolumn{4}{|c|}{ Rotation method: oblimin with Kaiser normalisation } \\
\hline
\end{tabular}

FIGURE 2: Preferred interpretation services. 
signs, brochures and so on (see Figure 2). The second most important factor was Factor 3, information structures, with a mean value of 4.15. Factor 2, activity involvement, received the lowest mean value of the three factors at 3.36. These factors concur with Orams' (1996) and Kuo's (2002) classification of hard interpretation through regulatory practices such as rules and regulations (Factor 1) and physical structures such as bird hides (Factor 3 ) and soft interpretation through education practices such as game drives with a field guide (Factor 2).

\section{Information and topics}

In Figure 3, respondents were asked to rate two aspects, namely what information should be presented at interpretation centres (i.e. topics) and the extent to which

\begin{tabular}{|c|c|c|}
\hline \multirow[t]{2}{*}{ Pattern matrix } & \multicolumn{2}{|c|}{ Component } \\
\hline & Factor 1 & Factor 2 \\
\hline \multicolumn{3}{|l|}{ Information should be presented on (visitors' agreement with each topic) } \\
\hline Historical sites in the park & 0.861 & - \\
\hline The surrounding cultures and/or communities of the park & 0.816 & - \\
\hline The history of the park & 0.787 & - \\
\hline The meaning of the park as a World Heritage park & 0.73 & - \\
\hline San or Bushmen of the Kgalagadi (e.g. their history, culture and way of life) & 0.683 & - \\
\hline The park related to South Africa, Namibia and Botswana & 0.64 & - \\
\hline This park in the context of South African national parks (i.e. SANParks) & 0.492 & - \\
\hline Archaeology of the park (i.e. human history and prehistory through excavations unique to the park) & 0.463 & - \\
\hline Nature & - & - \\
\hline Ecology of the park (i.e. relationships of organisms to one another and surroundings/environment) & - & -0.868 \\
\hline Fauna of the park (e.g. birds, insects, mammals, predators) & - & -0.819 \\
\hline Flora of the park (e.g. trees, flowers, plants) & - & -0.786 \\
\hline Geography of the park (i.e. the physical features of the earth and atmosphere unique to the park) & - & -0.765 \\
\hline Hydrology of the park (i.e. the movement, distribution and quality of the water in the park) & - & -0.68 \\
\hline Practical matters regarding conservation of the environment (e.g. recycling techniques or conserving water at home) & - & -0.479 \\
\hline Astrology (e.g. stargazing) that is accessible in this park & - & -0.468 \\
\hline Cronbach's alpha & 0.894 & 0.889 \\
\hline Mean value & 3.97 & 4.23 \\
\hline Inter-item correlation & 0.487 & 0.508 \\
\hline \multicolumn{3}{|l|}{ Extraction method: principal component analysis } \\
\hline \multicolumn{3}{|l|}{ Rotation method: oblimin with Kaiser normalisation } \\
\hline \multicolumn{3}{|l|}{ I would like information on this topic (visitors' desired extent of information) } \\
\hline \multicolumn{3}{|l|}{ Heritage } \\
\hline The meaning of this park as a transfrontier park & 0.906 & - \\
\hline The surrounding cultures and/or communities of the park & 0.846 & - \\
\hline The history of the park & 0.837 & - \\
\hline The meaning of the park as a World Heritage park & 0.78 & - \\
\hline This park in the context of South African national parks (i.e. SANParks) & 0.741 & - \\
\hline San or Bushmen of the Kgalagadi (e.g. their history, culture and way of life) & 0.693 & - \\
\hline Archaeology of the park (i.e. human history and prehistory through excavations unique to the park) & 0.512 & - \\
\hline \multicolumn{3}{|l|}{ Nature } \\
\hline Ecology of the park (i.e. relationships of organisms to one another and surroundings/environment) & - & 0.887 \\
\hline Flora of the park (e.g. trees, flowers, plants) & - & 0.867 \\
\hline Fauna of the park (e.g. birds, insects, mammals, predators) & - & 0.862 \\
\hline Climatology of the park (i.e. the park's climate and weather) & - & 0.842 \\
\hline Geography of the park (i.e. the physical features of the earth and atmosphere unique to the park) & - & 0.809 \\
\hline Hydrology of the park (i.e. the movement, distribution and quality of the water in the park) & - & 0.732 \\
\hline Astrology (e.g. stargazing) that is accessible in this park & - & 0.533 \\
\hline Practical matters regarding conservation of the environment (e.g. recycling techniques or conserving water at home) & - & 0.443 \\
\hline Cronbach's alpha & 0.936 & 0.919 \\
\hline Mean value & 3.53 & 3.99 \\
\hline Inter-item correlation & 0.622 & 0.594 \\
\hline
\end{tabular}

SANParks, South African National Parks.

FIGURE 3: Desired topics and extent of information in the interpretation centre. 


\begin{tabular}{|c|c|c|c|}
\hline \multicolumn{4}{|l|}{ Pattern matrix } \\
\hline \multirow[t]{2}{*}{ Variance $63.96 \%$} & \multicolumn{3}{|c|}{ Component } \\
\hline & Factor 1 & Factor 2 & Factor 3 \\
\hline \multicolumn{4}{|l|}{ Audio and visual } \\
\hline $\begin{array}{l}\text { Audiovisual media (e.g. videos that explain the } \\
\text { history of the park or evolution) }\end{array}$ & 0.834 & & \\
\hline $\begin{array}{l}\text { Visual media (e.g. pictures and diagrams to } \\
\text { present interesting information about the park) }\end{array}$ & 0.828 & & \\
\hline $\begin{array}{l}\text { Display of props or objects (e.g. archaeological, } \\
\text { plant, insect or cultural displays) }\end{array}$ & 0.816 & & \\
\hline Audio media (e.g. bird or animal sounds) & 0.78 & & \\
\hline $\begin{array}{l}\text { 2-D displays (e.g. posters with information on } \\
\text { the park) }\end{array}$ & 0.771 & & \\
\hline $\begin{array}{l}\text { 3-D displays (e.g. life-size examples of animals, } \\
\text { cultural artefacts or virtual tours) }\end{array}$ & 0.715 & & \\
\hline $\begin{array}{l}\text { Printed media (e.g. brochures on the } \\
\text { interpretation visitor centre and posters } \\
\text { with interesting information) }\end{array}$ & 0.701 & & \\
\hline $\begin{array}{l}\text { Virtual reality (e.g. virtual tours through } \\
\text { traditional dwellings of local cultures) }\end{array}$ & 0.595 & & \\
\hline $\begin{array}{l}\text { Technology-based media (e.g. interactive } \\
\text { touch screens that illustrate information } \\
\text { visitors would like to have) }\end{array}$ & 0.427 & & \\
\hline $\begin{array}{l}\text { Interpretation visitor centre tours led by a tour } \\
\text { guide }\end{array}$ & 0.356 & & \\
\hline \multicolumn{4}{|l|}{ Creative text } \\
\hline $\begin{array}{l}\text { Easily readable text or information in the } \\
\text { relevant media (e.g. a font that is not too small) }\end{array}$ & & 0.843 & \\
\hline $\begin{array}{l}\text { Absence of technical or academic terms in all } \\
\text { media }\end{array}$ & & 0.79 & \\
\hline Concise information presented in all media & & 0.783 & \\
\hline $\begin{array}{l}\text { Displays in all media should be lively, rich, } \\
\text { Vibrant and/or exciting }\end{array}$ & & 0.74 & \\
\hline $\begin{array}{l}\text { Game-like media (e.g. short quizzes, puzzles, } \\
\text { 'did you know' facts) }\end{array}$ & & 0.524 & \\
\hline $\begin{array}{l}\text { Staff in the interpretation visitor centre should } \\
\text { be able to answer any questions related to the } \\
\text { information presented }\end{array}$ & & 0.514 & \\
\hline \multicolumn{4}{|l|}{ Associations } \\
\hline $\begin{array}{l}\text { Souvenirs related to the interpretation centre } \\
\text { for sale as reminders of the experience }\end{array}$ & & & -0.491 \\
\hline $\begin{array}{l}\text { Size of the displays or media should reflect } \\
\text { life-size examples in order to relate to the } \\
\text { information presented }\end{array}$ & & & -0.443 \\
\hline Cronbach's alpha & 0.914 & 0.853 & 0.647 \\
\hline Mean value & 3.5 & 3.49 & 2.3 \\
\hline Inter-item correlation & 0.523 & 0.488 & 0.48 \\
\hline \multicolumn{4}{|l|}{ Extraction method: principal component analysis } \\
\hline Rotation method: oblimin with Kaiser normalisat & & & \\
\hline
\end{tabular}

FIGURE 4: Important media needed for interpretation in the visitor centre at Kgalagadi Transfrontier Park (interpretation centre).

they would like to receive information on specific topics in interpretation. Two factors were identified for both cases: nature and heritage. Both factors' Cronbach's alphas were above 0.8 , with inter-item correlations above 0.4 . Respondents rated nature as the most important factor for both information that should be presented at interpretation centres (mean value 4.23) and the specific topic they would like to receive the most information on (mean value 3.99). Therefore, education (interpretation) on nature is key for the interpretation centre in KTP. This research corresponds with the definitions of Geldenhuys (2009) and Fennell (2003), which highlight that tourism in natural settings must include interpretation and learning about the environment (environmental education). Heritage was also rated as significant, with mean values of 3.97 and 3.53. It is therefore also important to present information about the heritage of KTP in its interpretation centres.

\section{Interpretation media}

Media interpretation needed in the park was measured and is presented in Figure 4. Three factors were identified. Factor 1 was named 'audio and visual' because the two highest-ranking constructs were audio and video and because the rest of the constructs related to them. Factor 2 was named 'creative text', as the construct that measured the highest referred to easy, readable text, and the rest of the constructs related to how text is presented. Factor 3 was named 'associations', as the highest rating construct was souvenirs related to the interpretation, because tourists buy souvenirs to remind or associate themselves with tourism destinations they have visited. All three factors' Cronbach's alphas were above 0.6 , with inter-item correlations above 0.4. The factor with the highest mean value (3.50) was Factor 1 , audio and visual, followed by Factor 2, creative text, with a mean value of 3.49 ; the last was Factor 3, associations, with a mean value of 2.30 .

\section{Discussion}

The research set out to determine the interpretation needs and preferences of visitors to KTP, and three questions were asked to achieve the aim of the study: What interpretation services do tourists visiting KTP need? What topics or types of information are visitors interested in? Do visitors prefer that the topics or information be presented through specific mediums?

\section{Interpretation services needed by visitors}

The results revealed that the interpretation services needed are in the form of park guidelines, activity involvement and information structures. Park guidelines refer to rules and regulations, clear directions in the park and park maps. This makes perfect sense, as tourists spend most of their time within the park partaking in game drives and less time at the rest camps (Maciejewski \& Kerley 2014). Park guidelines are viewed as an inconspicuous form of interpretation, but as Kuo (2002) explains, they create an enjoyable visit where visitors can appreciate the value of the site. If all these aspects are well presented, they will influence learning and the overall experience of visitors in the park and therefore contribute to better interpretation within the park.

The second aspect, activity involvement, refers to cuisine experiences, events and local culture and therefore indicates that visitors to KTP require interpretation services that focus on the heritage and culture within the park. This was confirmed by Mearns and Botha (2017), who explain that heritage and culture form part of natural area interpretation. As indicated in the literature, this park has plenty to offer regarding culture and heritage, as it is a WHS. Currently, as stated by Moore (2017), the park lacks interpretation in this regard, thereby confirming what park management expected.

Information structures are the third interpretation service identified by visitors as important for a quality experience in 
the park. This includes structures such as bird hides, lookout points, information boards and tree identification. The park does possess a variety of lookout points, picnic areas and hides (SANparks 2020b). Management can review these sites and identify ways in which different topics could perhaps be linked through additional approaches. As one would not want to distract from the aesthetics of the natural area, or provide too much or irrelevant information, a possible solution could be to add quick response (QR) scan codes, for example at tree identification nameplates, where tourists can find additional information on the tree.

\section{Interpretation topics}

The research revealed that the main interpretation topics visitors are interested in are about nature and heritage and that the extent of information they prefer is quite high. Similar to other national parks, KTP was established to protect the natural environment, and it is not surprising that visitors would like to receive information about nature during their stay. However, the park was only recently (i.e. 2017) inscribed as a WHS because of the unique cultural landscape, and it was interesting to see the strong preference for heritage information that is currently absent from the park (Moore 2017). This is an aspect that requires immediate attention.

\section{Specific mediums through which the topics or information should be presented}

The research identified three mediums through which visitors would like to receive interpretation in an interpretation centre, namely audio and visual, creative text and associations. As stated by the visitor manager of SANParks, currently the park lacks such a centre (Moore 2017), and identifying the mediums through which the previous identified topics (nature and heritage) should be displayed will help with the design of such a centre.

When considering the preferred mediums, it is evident that the visitors are in need of technological forms of interpretation (audio and visual), which are currently not on offer in the limited interpretation offerings (Mearns \& Botha 2017; Moore 2017). It is also evident from the results that careful consideration should be given to the delivery of information. As Ham (1992) explains, interpretation should be enjoyable, personally relevant and organised, and it is therefore not surprising that visitors prefer information that is creative, fun (i.e. game-like), non-technical and concise.

Considering that visitors tend to spend more time within the park than at rest camps, it could be worthwhile to incorporate interpretation through mobile devices that tourists can access during their self-drives. An interactive map could highlight points of interest related to either nature or heritage, where on-site interpretation (at the points of interest) could be useful for additional information (such as through the use of QR codes as explained earlier).

\section{Conclusion}

The aim of this research was to determine the interpretation needs and preferences of visitors to KTP, and to address this aim, three questions were raised: What are the interpretation service preferences of tourists visiting this national park? What are the topics or types of information visitors are interested in? Do visitors prefer specific mediums through which the topics and information should be presented? The answers to these questions revealed several practical implications for the design of interpretation services in KTP based on tourists' needs and preferences rather than park management's needs and preferences.

Customising interpretation services to the tourists' needs and preferences may add to the visitors' enjoyment, create loyalty, extend stays, and increase expenditure and revenue for parks (Mearns \& Botha 2017). Interpretation is therefore no longer seen as a 'luxury' service but is rather viewed worldwide as an essential management function of national parks, and this is also the case in KTP.

The research makes the following contributions to the field of interpretation in ecotourism and natural area tourism. First, this study was the first of its kind conducted in KTP regarding interpretation. Second, the study revealed the preferred interpretation services, topics, extent of information and media for interpretation, which will assist management with interpretation development and management.

As this research focused on the general needs and preferences of tourists for interpretation services, context (i.e. topics) and media, it would be worthwhile to research effective approaches to deliver specific themes (i.e. messages about the topics). It would also be valuable to determine whether there are specific thresholds of information consumption (extent of information) per specific medium of interpretation to determine the most suitable medium for each topic.

\section{Acknowledgements}

The authors acknowledge South African National Parks for the opportunity to conduct this research and for its support.

\section{Competing interests}

The authors declare that they have no conflicts of interest.

\section{Authors' contributions}

All authors contributed to the study conception and design. Material preparation and data collection were performed by P.v.d.M., M.S. and E.B. The literature was written by E.B.; the methodology, results and findings were written by P.v.d.M. All authors had the opportunity to comment on one another's versions, and all read and approved the final manuscript. 


\section{Funding information}

This research was funded by South African National Parks.

\section{Data availability statement}

The raw data of this study will not be made available to external third parties, as this was not applied for during the ethics clearance process, and consequently, the respondents have not provided consent to do so.

\section{Disclaimer}

The views expressed in this article are those of the authors and are not an official position of the institution or funder.

\section{References}

Ballantyne, R., Hughes, K. \& Bond, N., 2016, 'Using a Delphi approach to identify managers' preferences for visitor interpretation at Canterbury Cathedral World Heritage Site', Tourism Management 54(June), 72-80. https://doi.org/10.1016/j. tourman.2015.10.014

Ballantyne, R., Packer, J. \& Falk, J., 2011, 'Visitors' learning for environmental sustainability: Testing short- and long-term impacts of wildlife tourism experiences using structural equation modelling', Tourism Management 32(6), 1243-1252. https://doi.org/10.1016/j.tourman.2010.11.003

Ballantyne, R., Packer. J. \& Hughes, K., 2009, 'Tourists' support for conservation messages and sustainable management practices in wildlife tourism experiences' Tourism Management 30(5), 658-664. https://doi.org/10.1016/j.tourman.2008.11.003

Ballantyne, R., Packer, J. \& Sutherland, L.A., 2011, 'Visitors' memories of wildlife tourism: Implications for the design of powerful interpretive experiences', Tourism Management 32(4), 770-779. https://doi.org/10.1016/j.tourman.2010.06.012

Botha, E., Saayman, M. \& Kruger, M., 2016, 'Expectations versus experience - The Kruger National Park's interpretation services from a regional approach', Journal of Ecotourism 15(2), 158-183. https://doi.org/10.1080/14724049.2016.1178753

Bidder, C., Kibat, S.A. \& Fatt, B.S., 2016, 'Cultural interpretation toward sustainability: A case of Mount Kinabalu', Procedia: Social and Behavioural Sciences 224(15) 632-639. https://doi.org/10.1016/j.sbspro.2016.05.454

Carmody, J. \& Prideaux, B., 2011, 'Enhancing the role of host communities in the management of protected areas through effective two-way communications: A case study', Asia Pacific Journal of Tourism Research 16(1), 89-104. https://doi. org/10.1080/10941665.2011.539393

Ceballos-Lascurain, H., 1987, 'The future of ecotourism', Mexico Journal (January), 13-14.

Chen, W.Y. \& Jim, C.Y., 2012, 'Contingent valuation of ecotourism development in country parks in the urban shadow', International Journal of Sustainable Development \& World Ecology 19(1), 44-53. https://doi.org/10.1080/13504509.2011.588727

Cheung, L.T.O. \& Jim, C.Y., 2013, 'Ecotourism service preference and management in Hong Kong', International Journal of Sustainable Development \& World Ecology 21(2), 149-159. https://doi.org/10.1080/13504509.2013.859183

Cheung, L.T.O. \& Jim, C.Y., 2014, 'Expectations and willingness-to-pay for ecotourism service in Hong Kong's conservation areas', International Journal of Sustainable Development \& World Ecology 20(2), 182-194. https://doi.org/10.1080/1350450 9.2013.775192

Cohen, J.W., 1988, Statistical power analysis for the behavioural sciences, 2nd edn., L. Erlbaum Associates, Hillsdale, NJ.

De Rojas, C. \& Camarero, C., 2008, 'Visitors' experience, mood and satisfaction in a heritage context: Evidence from an interpretation centre', Tourism Management 29(3), 525-537. https://doi.org/10.1016/j.tourman.2007.06.004

De Witt, L., Van der Merwe, P. \& Saayman, M., 2015, 'Key environmental management factors in protected areas: An eco-tourist perspective', African Journal of Hospitality, Tourism and Leisure 4(2), 1-12.

Dioum, B., 1968, Paper presented at the General Assembly of the International Union for the Conservation of Nature and Natural Resources, New Delhi: Seattle Public Library Archive.

Du Plessis, L., Van der Merwe, P. \& Saayman, M., 2013, 'Tourist perception on whether South African national parks are environmentally friendly', Acto Academica 44(3), 52-76.

Eagles, P.F.J., 2014, 'Research priorities in park tourism', Journal of Sustainable Tourism 22(4), 528-549. https://doi.org/10.1080/09669582.2013.785554

Fennell, D., 2003, Ecotourism: An introduction, 4th edn., SAGE, London.

Field, A., 2013, Discovering statistics using SPSS, 2nd edn., SAGE, New York, NY.

Geldenhuys, S., 2009, 'Ecotourism criteria and context', in M. Saayman (ed.), Ecotourism: Getting back to basics, pp. 1-24, Institute for Tourism and Leisure Studies, Potchefstroom.

Haely, N., Van Riper, C.J. \& Boyd, S.W., 2016, 'Low versus high intensity approaches to interpretive tourism planning: The case of the Cliffs of Moher, Ireland', Tourism Management 52(February), 574-583. https://doi.org/10.1016/j.tourman.2015. 08.009
Ham, S., 1992, Environmental interpretation: A practical guide for people with big ideas and small budgets, North American Press, Golden, CO.

Ham, S., Housego, A. \& Weiler, B., 2005, Tasmanian thematic interpretation planning manual, Tourism Tasmania, Hobart.

Ham, S.H. \& Weiler, B., 2006, Development of a research-based tool for evaluating interpretation, CRC for Sustainable Tourism, Gold Coast.

Henker, K.B. \& Brown, G., 2011, 'As good as the real thing? A comparative study of interpretive podcasts and traditional ranger talks', Journal of Interpretation Research 16(1), 7-23.

Hermann, U.P., Van der Merwe, P., Coetzee, W.J.L. \& Saayman, M., 2015, 'A visitor perspective of conservation management at a South African national park and World Heritage Site', African Journal of Hospitality Tourism and Leisure 4(1), 1-11.

Jacobs, M.H. \& Harms, M., 2014, 'Influence of interpretation on conservation intentions of whale tourists', Tourism Management 42(June), 123-131. https://doi.org/10.1016/j.tourman.2013.11.009

Jurdana, D.S., 2009, 'Specific knowledge for managing ecotourism destinations', Tourism Hospitality Management 15(2), 267-278.

Kaiser, H., 1974, 'An index of factorial simplicity', Psychometrika 39(1), 31-36. https://doi.org/10.1007/BF02291575

Kang, M. \& Gretzel, U., 2012, 'Effects of podcast tours on tourist experiences in a national park', Tourism Management 33(2), 440-455. https://doi.org/10.1016/j tourman.2011.05.005

Keyton, J. \& Beck, S.T. 2010, 'Perspective: Examining communication as macrocognition in STS', Human Factors 52(2), 335-339. https://doi.org/10.1177/0018720810371338

Kolb, D.A., 1984, Experiential learning: Experience as the source of learning and development, Prentice-Hall, Englewood Cliffs, NJ.

Krejcie, R.V. \& Morgan, D.W. 1970, 'Determining sample size for research activities', Educational and Psychological Measurement 30(3), 607-610. https://doi. Educational and Psychological Meas
$\mathrm{org} / 10.1177 / 001316447003000308$

Kuo, I., 2002, 'The effectiveness of environmental interpretation at resource-sensitive tourism destinations', International Journal of Tourism Research 4(2), 87-101. https://doi.org/10.1002/jtr.362

Langer, E.J., 1989, 'Minding matters: The consequences of mindlessness-mindfulness', Advances in Experimental Social Psychology 22, 137-173. https://doi.org/ 10.1016/S0065-2601(08)60307-X

Lee, T.H., 2009, 'A structural model for examining how destination image and interpretation services affect future visitation behaviour: A case study of Taiwan's Taomi eco-village', Journal of Sustainable Tourism 17(6), 727-745. https://doi.org/ 10.1080/09669580902999204

Lück, M., 2015, 'Education on marine mammal tours - But what do tourists want to learn?', Ocean \& Coastal Management 103(January), 25-33. https://doi.org/ 10.1016/j.ocecoaman.2014.11.002

Maciejewski, K. \& Kerley, G.I.H., 2014, 'Understanding tourists' preference for mammal species in private protected areas: Is there a case for extralimital species for ecotourism?', PLoS One 9(2), 1-8, viewed 30 April 2020, from https:// journals. plos.org/plosone/article/file?id=10.1371/journal. pone.0088192\&type= printable.

Marschall, S., Granquist, S.M. \& Burns, G.L., 2017, 'Interpretation in wildlife tourism: Assessing the effectiveness of signage on visitor behaviour at a seal watching site in Iceland', Journal of Outdoor Recreation and Tourism 17(March), 11-19. https://doi.org/10.1016/j.jort.2016.11.001

Mearns, K. \& Botha, E., 2017, 'The roles of interpretation in the management of National Parks in South Africa', in M.Z. Suratman (ed.), Management and conservation, IntechOpen, viewed 30 April 2020, from https://www.intechopen. $\mathrm{com} /$ books/national-parks-management-and-conservation/the-roles-ofinterpretation-in-the-management-of-national-parks-in-south-africa.

Mitsche, N., Reino, S., Knox, D. \& Bauernfeind, U., 2008, 'Enhancing cultural tourism e-services through heritage interpretation', in P.O'Connor, W. Höpken \& U. Gretzel (eds.), Information and communication technologies in tourism 2008: Proceedings of the International Conference in Innsbruck, Austria 2008, pp. 419-429, Wien, Springer, New York, NY.

Moore, K., 2017, Interpretation needs for Kgalagadi transfrontier park [personal interview], 17 Jan 2017, Kgalagadi Transfrontier Park.

Moscardo, G., 2014, 'Interpretation and tourism: Holy grail or emperor's robes?', International Journal of Culture, Tourism and Hospitality Research 8(4), 462-476. https://doi.org/10.1108/IJCTHR-08-2014-0071

Moscardo, G. \& Ballantyne, R., 2008, 'Interpretation and attractions', in A. Fyall, B. Garrod, A. Leask \& S. Wanhill (eds.), Managing visitor attractions, 2nd edn., pp. 237-252, Elsevier, Oxford.

Orams, M., 1994, 'Creating effective interpretation for managing interaction between tourists and wildlife', Australian Journal of Environmental Education 10(1), 21-34. https://doi.org/10.1017/S0814062600003062

Orams, M., 1996, 'A conceptual model of tourist-wildlife interaction: The case for education as a management strategy', The Australian Geographer 27(1), 39-51. https://doi.org/10.1080/00049189608703156

Quinlan, C., Babin, B., Carr, J., Griffin, M. \& Zikmund, W., 2019, Business research methods, 2nd edn., Cencage, United Kingdom.

Reisinger, Y. \& Steiner, C., 2006, 'Reconceptualising interpretation: The role of tour guides in authentic tourism', Current Issues in Tourism 9(6), 481-498. https://doi. org/10.2167/cit280.0

Saayman, M. \& Van der Merwe, P., 2017, 'Identifying ecotourist accommodation needs and preferences', The South African Journal of Business Management 48(1), 67-75. https://doi.org/10.4102/sajbm.v48i1.21 
SANParks (South African National Parks), 2018, Annual report 2017/2018, viewed 28 April 2020, from https://www.sanparks.org/assets/docs/general/annualreport-2018.pdf

SANParks (South African National Parks), 2020a, Kgalagadi Transfrontier Park: Natural \& cultural history, viewed 28 April 2020, from https://www.sanparks.org/parks/ kgalagadi/tourism/history.php.

SANParks (South African National Parks), 2020b, Kgalagadi Transfrontier Park, viewed 30 April 2020, from https://www.sanparks.org/parks/kgalagadi/.

Schiffman, L.G. \& Kanuk, L.L., 2007, Consumer behaviour, 8th edn., Prentice Hall, Upper Saddle River, NJ.

Schindler, A., Ruoppolo, G. \& Barillari, U., 2010, 'Communication and its disorders: Definition and taxonomy from a phoniatric perspective', Audiological Medicine 8(4), 163-170. https://doi.org/10.3109/1651386X.2010.530023

Sheena, B., Mariapan, M. \& Aziz, A., 2015, 'Characteristics of Malaysian ecotouris segments in Kinabalu Park, Sabah', Tourism Geographies 17(1), 1-18. https://doi. org/10.1080/14616688.2013.865069

South Africa, 2003, Protected Areas Act 57 South Africa (2003), Author, Cape Town, South Africa.

South Africa (Department of Environmental Affairs), 2019, Transfrontier Conservation Areas, viewed 28 April 2020, from https://www.environment.gov.za/ projectsprogrammes/transfrontier_conservation_areas\#kgalakgadi.

South Africa (International Relations and Cooperation), 2004, Transfrontier Conservation Areas (TFCAs), viewed 15 July 2019, from http://www.dirco.gov.za/ foreign/Multilateral/inter/tfcas.htm.
South African Government, 1976, National Parks Act 57 South Africa (1976), Author Cape Town, South Africa.

Stewart, E.J., Hayward, B.M., Devlin, P.J. \& Kirby, V.G., 1998, 'The 'place' of interpretation: A new approach to the evaluation of interpretation', Tourism Management 19(3), 257-266. https://doi.org/10.1016/S0261-5177(98) 00015-6

Tilden, F., 1977, Interpreting our heritage, 3rd edn., University of North Carolina Press, Chapel Hill, NC.

United Nations Educational, Scientific and Cultural Organisation (UNESCO), 2019a, ¥Khomani cultural landscape, viewed 15 July 2019, from http://whc.unesco.org/ en/list/1545.

United Nations Educational, Scientific and Cultural Organisation (UNESCO), 2019b, State parties: South Africa, viewed 15 July 2019, from http://whc.unesco.org/en/ statesparties/ZA/.

Van der Merwe, P. \& Saayman, M., 2008, 'Travel motivation of visitors to the Kruger National Park', Koedoe 50(1), 154-159. https://doi.org/10.4102/koedoe. v50i1.140

Van der Merwe, P., Saayman, M. \& Pienaar, J., 2009, 'Expenditure-based segmentation of tourists to the Kruger National Park', Acta Academica 41(3), 107-127.

Ward, C.W. \& Wilkinson, A.E., 2006, Conducting meaningful interpretation: A field guide for success, Fulcrum Publishing, Golden, $\mathrm{CO}$.

Zeppel, H. \& Muloin, S., 2008, 'Conservation benefits of interpretation on marine wildlife tours', Human Dimensions of Wildlife 13(4), 280-294. https://doi. org/10.1080/10871200802187105 